\title{
Photosynthesis, growth, and survival in seedlings of four tropical fruit-tree species under intense radiation
}

\author{
Daniel ORTIZ1 ${ }^{\text {, Flavio MORENO², Maria Claudia DÍEZ }}{ }^{2 *}$ (i) \\ Corporación Colombiana de Investigación Agropecuaria - AGROSAVIA, Centro de Investigación Palmira - Sede Popayán, Calle 8a Norte \# 10 - 68, Popayán, \\ Colombia \\ 2 Universidad Nacional de Colombia, Sede Medellín, Facultad de Ciencias Agrarias, Carrera 65 \# 59 A - 110, Medellín, Colombia \\ * Corresponding autor: mcdiez@unal.edu.co; (D) https://orcid.org/0000-0003-0066-9866
}

\begin{abstract}
In the Amazon region, agroforestry systems (AFSs) are recommended as a sustainable production alternative for local communities. A common component in Amazonian AFSs are tropical fruit trees, which can form the canopy or grow in the understory. In this study, we evaluated the effect of high radiation on photosynthesis, growth and seedling survival of four Amazonian fruit-tree species: Theobroma cacao, Eugenia stipitata, Inga edulis and Psidium guajava. Growth, chlorophyll fluorescence, gas exchange, and leaf pigments were measured in seedlings of each species grown for 12 months inside shade houses with low (8\%), medium (30\%) and high relative illumination (100\%). Eugenia stipitata and T. cacao had the lowest acclimation capacity to high solar radiation, followed by $I$. edulis. Therefore, these species must be grown under intermediate light levels in early growth stages, to protect them from direct sunlight. In contrast, P. guajava seedlings demonstrated high tolerance to elevated radiation, therefore, this species can be planted under full sunlight.
\end{abstract}

KEYWORDS: acclimation, agroforestry systems, carotenoids, chloroplasts, photosystem II

\section{Fotosíntesis, crecimiento y supervivencia en plántulas de cuatro especies de árboles frutales tropicales bajo intensa radiación}

\section{RESUMEN}

En la región amazónica, los sistemas agroforestales (SAFs) se recomiendan como una alternativa de producción sustentable para las comunidades locales. Un componente común en los SAFs amazónicos son los árboles frutales tropicales, que pueden formar parte del dosel o crecer en el sotobosque. En este trabajo, estudiamos el efecto de la radiación alta sobre la fotosíntesis, el crecimiento y la supervivencia de cuatro especies de árboles frutales amazónicos: Theobroma cacao, Eugenia stipitata, Inga edulis y Psidium guajava. Se midieron el crecimiento, fluorescencia de clorofila, intercambio de gases y pigmentos foliares en plántulas de cada especie que crecieron durante 12 meses dentro de casa-mallas en baja (8\%), media (30\%) y alta iluminación relativa (100\%). Eugenia stipitata y T. cacao tuvieron la menor capacidad de aclimatación a la radiación solar alta, seguidas por I. edulis. En consecuencia, esas especies deben sembrarse bajo niveles de luz intermedia, para protegerlas del sol directo en las etapas iniciales de crecimiento. En contraste, las plántulas de P. guajava mostraron alta tolerancia a la elevada radiación solar, por lo que esta especie puede ser plantada bajo libre exposición solar.

PALABRAS CLAVE: aclimatación, sistemas agroforestales, carotenoides, cloroplastos, fotosistema II

\section{INTRODUCTION}

Light intensity is a key factor for the establishment and growth of plants in agroforestry systems (AFSs), as the light environment below the canopy is variable and significantly affects the assimilation of $\mathrm{CO}_{2}$ and the development of plants growing in the understory (Charbonnier et al. 2017). Seedlings of an AFS can be exposed to high radiation, as in full sunlight, when canopy-trees are young or when the spacing among them is wide, which could negatively affect their growth and survival. Full sunlight intensity, typical of open field conditions, may also affect the establishment of canopy-tree seedlings, because radiation values usually exceed the light saturation point (LSP) of photosynthesis of many tropical fruit-tree species (Krause et al. 2012). Since young plants of several species used in AFSs are particularly vulnerable to light stress, intense radiation could cause photoinhibitory processes that affect their survival and growth, and consequently the AFS productivity (Goh et al. 2012).

In tropical forests, light requirements and tolerance of seedlings to shading are the major features used to classify 
forest-tree species into two main ecological groups: shadeintolerant or pioneer species and shade-tolerant or latesuccessional species (Bazzaz and Pickett 1980). Functional leaf traits significantly differ among these groups, however they have not yet been clearly elucidated in several Amazonian fruit-tree species. Physiological, anatomical, and biochemical traits, and particularly the photosynthetic capacity and tolerance to photoinhibition, are a matter of scientific interest (Yang et al. 2020).

Pioneer species show higher responsiveness to high irradiance than late-successional ones (Cazzonelli 2011; Favaretto et al. 2011). They require either high capacity to dissipate excess light energy or flexibility in their protective systems to adjust to these environments through increase in carotenoids, modulation of the photosystem II (PSII), and elevated content of the photosynthetic enzyme Rubisco (Nilkens et al. 2010; Favaretto et al. 2011; Demmig-Adams et al. 2012). Shade-tolerant species, on the other hand, are prone to chlorophyll degradation and to suffer chronic photoinhibition, the latter being defined as the slow, irreversible decline in the maximum photochemical efficiency of PSII $(\mathrm{Fv} / \mathrm{Fm})$ that occurs when the absorbed light is in excess of what is required for carbon assimilation, which may eventually compromise plant survival (Krause et al. 2012). This phenomenon occurs because leaves have high concentration of chlorophyll, higher light-capturing capacity due to the larger antenna size of the PSII, lower LSP of photosynthesis and lower amounts of the photosynthetic enzyme Rubisco (Favaretto et al. 2011; Vass 2012). Photoinhibition is very frequent in plants of the tropics, where light intensity can reach values over $1800 \mu \mathrm{mol}$ photons $\mathrm{m}^{-2} \mathrm{~s}^{-1}$ (Krause et al. 2012). Therefore, considering the susceptibility of Amazonian fruit-tree species to photoinhibition, knowledge on their ability to acclimate to full sun becomes relevant to enhance success of AFS implementation (Tremblay et al. 2015).

Theobroma cacao L. (Malvaceae) and Eugenia stipitata Mc Vaugh (Myrtaceae) are small-sized trees native to the Amazon and are economically important in countries such as Brazil, Colombia, Ecuador and Peru due to the high demand for their fruits (Abbott et al. 2018). In their natural habitats, they grow in the understory, generally in low-light conditions, which explains why they have been cultivated under the canopy of diverse native species in AFSs (García et al. 2011; Avila-Lovera et al. 2016). Inga edulis Mart. (Fabaceae) and Psidium guajava L. (Myrtaceae) are among the medium-sized tree species more commonly used for shading in AFSs of the Amazon region (Braga et al. 2019). They have been widely used due to their tolerance to acidic soils, their production of edible fruits, and the supply of important nutrients to associated species (Nichols and Carpenter 2006). Frequently, these species have been planted in forest gaps or between forest remnants, where solar radiation is intense (Rai et al. 2010; Nygren et al. 2013).
This study aimed to evaluate the effect of intense radiation on photosynthesis, growth, and survival of young plants of four tropical fruit-tree species with different light requirements: T. cacao, E. stipitata, I. edulis, and P. guajava. This knowledge is fundamental to improve the management of light environments in the initial stages of plant establishment for these species in AFSs. Our hypothesis was that the four species differ in their acclimatization capacity to counteract the potentially damaging effects of intense radiation.

\section{MATERIAL AND METHODS}

\section{Study area and plant material}

The study was carried out at the Cotové Agrarian Station of Universidad Nacional de Colombia, located in the municipality of Santa Fé de Antioquia (Colombia)

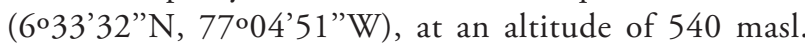
Average annual temperature is $27{ }^{\circ} \mathrm{C}$ and rainfall is 1100 $\mathrm{mm}$ (Pérez and Barreiro 1986). Two of the studied species are shade-tolerant (E. stipitata and T. cacao), one has medium tolerance to shade (I. edulis) and one is a pioneer species ( $P$. guajava) (Zuidema et al. 2005; Lojka et al. 2010; Fischer et al. 2012).

Eugenia stipitata seedlings with approximately $8 \mathrm{~cm}$ in height were selected and collected from an area with natural regeneration of an existing AFS at the station. Inga edulis, P. guajava and T. cacao seeds were sown in a germination bed with washed river sand. When four to five leaves had emerged, the seedlings were transplanted to 1.5 -L plastic bags containing a mix of local organic soil, compost and rice husk in a 2:2:1 proportion. Chemical fertilization was carried out with $20 \mathrm{~g}$ of 15-15-15 (NPK) per bag. Irrigation was applied every other day up to field capacity calculated by gravimetric humidity. Seedlings were acclimated to intermediate light levels ( $40 \%$ relative illumination - RI) for one month. Plants were sprayed with preventive applications of Lorsban to control pests (spray concentration of $48 \%$ Chlorpyrifos) at a concentration of $0.2 \%$ in water.

\section{Light conditions}

Three light treatments were established through the construction of wooden structures covered with shade cloth. Each treatment had five repetitions for a total of 15 experimental units (i.e. wooden structures) and three plants per species in each experimental unit (a total of 45 plants per species and 180 plants in the whole experiment). Using the radiation data recorded simultaneously inside and outside the shade houses, the relative illumination (RI) of the three light treatments were determined as: $8 \%, 31 \%$ and $100 \%$. The maximum daily radiation received by the plants of each treatment was estimated from photosynthetic active radiation (PAR) data measured with quantum sensors (Li-190R, LI- 
COR', Lincoln, NE, USA) for three months, selecting the values of clear days (without clouds).

\section{Growth evaluation}

At the start and the end of the study, five individuals of each species were harvested for each light treatment in order to determine the total biomass of roots, stems, and leaves. The plant material was dried in an oven at $105^{\circ} \mathrm{C}$ for 48 hours or until constant weight. The relative growth rate $(R G R)$ was calculated with equation 1.

$$
R G R=\frac{\ln X_{2}-\ln X_{1}}{T_{2}-T_{1}}
$$

where $\ln$ is natural logarithm, $X_{2}$ and $X_{1}$ are the biomass, height, or diameter, final and initial, of the plant, respectively, and $T_{2}-T_{1}$ is the trial time interval, which was 365 days (12 months).

\section{Foliar pigment quantification}

The pigment content was determined in a sample composed of three $1-\mathrm{cm}$ diameter leaf discs, corresponding to three individuals of each species in each shade house. A mature leaf from the middle third of each individual was selected. The discs were frozen in liquid nitrogen at $-70^{\circ} \mathrm{C}$ and subsequently stored in a freezer at $-80^{\circ} \mathrm{C}$ until determination. The protocol proposed by Lichtenthaler and Willburn (1983) was used to extract and quantify chlorophyll $a$ and $b$, and total carotenoids, with $80 \%$ acetone as extractor. Equations 2 to 5 developed by Lichtenthaler (1987) were used to obtain the concentration of chlorophylls (Chlo) and total carotenoids (Tot car) $\left(\mathrm{mg} \mathrm{g}^{-1}\right)$.

$$
\begin{aligned}
& \text { Chlo } a=\left(12.25^{*} A_{663 n \mathrm{~m}}\right)+\left(2.79^{*} A_{647 \mathrm{~nm}}\right) \\
& \text { Chlo } b=\left(21.5^{*} A_{647 \mathrm{~nm}}\right)+\left(5.1^{*} A_{663 \mathrm{~nm}}\right) \\
& \text { Total Chlo }=(\text { chlo } a+\text { chlo } b) \\
& \text { Tot car }=\frac{\left(1000 * A_{470} \mathrm{~nm}\right)-(1.82 * \text { chlo } a)-(85.02 * \text { chlo } b)}{198}
\end{aligned}
$$

\section{Chlorophyll fluorescence}

The chlorophyll fluorescence was measured with the procedure described by Barth and Krause (1999) with an optic fluorometer (OS-30p, Opti Sciences, Hudson, USA). The maximum photochemical efficiency of photosystem II (Fv/ $\mathrm{Fm}$ ) of seedlings was calculated through the determination of the ratio between fluorescence $(\mathrm{Fv})$ and maximum fluorescence $(\mathrm{Fm})$ in dark-adapted leaves. Measurements were done at the end of the experimental period (12 months after establishment) in the same leaves used to measure photosynthesis. In order to evaluate the changes in $\mathrm{Fv} / \mathrm{Fm}$ throughout the day, measurements were taken in the morning (8:00-10:00 am), at midday (12:00-2:00 pm) and in the afternoon (4:00-6:00 pm). Before measurements, leaves were dark-adapted for 25 minutes in order to let all components of the electron transport chain achieve complete oxidation (open). Afterwards, a high intensity actinic light was shone for one second $\left(2000 \mu \mathrm{mol} \mathrm{m}^{-2} \mathrm{seg}^{-1}\right)$.

\section{Gas exchange measurements}

Photosynthesis and stomatal conductance were measured in leaves of three individuals of each species per treatment, selected at random in different shade houses. For this, mature leaves from the middle third of plants were selected and a Portable Photosystem System (LI- 6400 XT, LI$\mathrm{COR}^{\circ}$, Lincoln, NE, USA) equipped with a controlled light source (6400-02B red-blue) was used. Measurements of photosynthesis in response to different light intensities were performed with the AUTOPROGRAM light-curve tool available in the software of the equipment. Photosynthetic photon flux densities (PPFD) were fixed at 0, 20, 50, 100, 250, 500 and $1000 \mu \mathrm{mol}$ photons $\mathrm{m}^{-2} \mathrm{~s}^{-1}$. Measurements were carried out in descending order of PPFD after the leaf was acclimated to the maximum value for 15 minutes. Other configurations of the equipment during measurements were: air flow rate of $400 \mu \mathrm{mol} \mathrm{s}^{-1}, \mathrm{CO}_{2}$ concentration of $400 \mathrm{ppm}$, relative humidity in the chamber of $75 \% \pm 3 \%$, and block temperature of $27 \pm 1{ }^{\circ} \mathrm{C}$.

Curves of photosynthesis in response to PPFD were estimated through non-linear regression with an exponential model proposed by Iqbal et al. (1997) (Equation 6). This model was chosen because it produced the best fit between the measured and the estimated data (dos Santos et al. 2013).

$$
P n=\left(A_{\max }+R_{d}\right)\left(1-e^{-\frac{-\alpha P A R}{A_{\max } R_{d}}}\right)-R_{d}
$$

where $P_{n}$ is the net photosynthesis $\left(\mu \mathrm{mol} \mathrm{CO}_{2} \mathrm{~m}^{-2} \mathrm{~s}^{-1}\right)$; $\mathrm{A}_{\max }$ is the maximum photosynthesis rate $\left(\mu \mathrm{mol} \mathrm{CO} \mathrm{Cm}^{-2} \mathrm{~s}^{-1}\right)$; PAR is the photosynthetically active radiation ( $\mu$ mol photons $\left.\mathrm{m}^{-2} \mathrm{~s}^{-1}\right) ; \alpha$ is the apparent quantum efficiency and represents the slope of the initial part of the curve (a non-dimensional measurement); $R_{d}$ is the dark respiration rate and corresponds to the $P_{n}$ value $\left(\mu \mathrm{mol} \mathrm{CO} \mathrm{CO}^{-2} \mathrm{~s}^{-1}\right)$ when $P A R=0$.

\section{Statistical analysis}

Data of, $A_{\text {max }}$, RGR, foliar area, total biomass, stomatal conductance and pigment content were compared among treatments within species with simple analyses of variance (ANOVA) for a completely random statistical design, while maximum chlorophyll photochemical efficiency of photosystem II in dark-adapted leaves $(\mathrm{Fv} / \mathrm{Fm})$ was analyzed within species with a two-way ANOVA for a factorial design, with light treatment and time of day as independent factors. The statistical significance of differences among treatments was evaluated with a Fisher's LSD test. The survival was analyzed with a chi-square test for comparison of proportions. All statistical tests were carried out with STATGRAPHICS Centurion version XVI". 


\section{RESULTS}

\section{Light treatments}

The maximum ambient PAR values were recorded between 12:00 $\mathrm{pm}$ and 1:00 pm, with mean values of maximum radiation of 2000, 600 and $150 \mu \mathrm{mol} \mathrm{m} \mathrm{seg}^{-1}$ in the light treatments of $100 \%, 31 \%$ and $8 \%$ of RI, respectively (Figure 1).

\section{Growth}

All tests were significant for foliar area (all tests $\mathrm{p}<$ 0.0001 ), total biomass (all tests $\mathrm{p}<0.0001$ ) and RGR for biomass, height and diameter (all tests $\mathrm{p}<0.034$ ). The general pattern of foliar area, total biomass and growth rate for biomass, height and diameter was similar within species (Figure 2; Table 1). In P. guajava, the RGR, total biomass and foliar area increased as a function of the radiation level, with the highest values recorded at $100 \%$, followed by $31 \%$ RI (Figure 2). However, the difference between the two latter treatments was not significant. Eugenia stipitata, T. cacao and I. edulis presented some common patterns; for example, at intermediate radiation ( $31 \% \mathrm{RI})$ they had the highest foliar area, RGR and total biomass, which were significantly reduced in the treatment of direct sunlight (100\%).

\section{Pigment content}

The four species exhibited a significantly decreasing trend in total chlorophyll content (all tests $\mathrm{p}<0.0001$ ) as the radiation level increased, which was more pronounced in the leaves of E. stipitata and T. cacao (Table 1). Eugenia stipitata had the strongest response, with a content decrease of $69 \%$ between $31 \%$ and $100 \%$ RI, followed by $T$. cacao, with a decrease of $61 \%$. These results agree with field observations in leaves of the upper third of trees of these species, which presented slight chlorosis. On the other hand, the decrease in the chlorophyll content of I. edulis and P. guajava was lower, between 25 and $39 \%$.

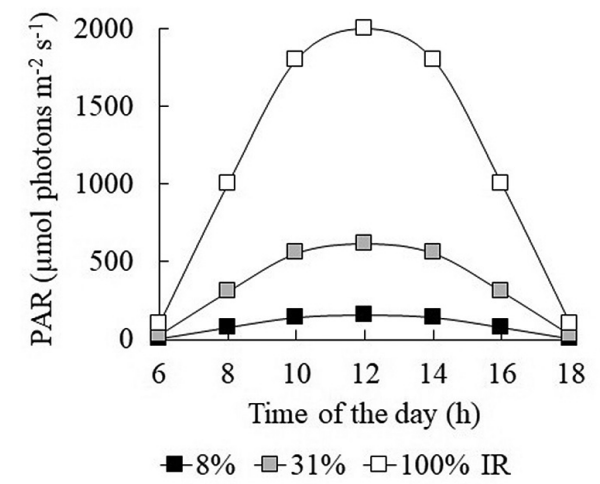

Figure 1. Daily course of photosynthetically active radiation (PAR) in the three light treatments (8, 31 and 100\% RI) established to evaluate the response of Eugenia stipitata, Theobroma cacao, Inga edulis, and Psidium guajava seedlings.
There was a significant effect of light level on total carotenoid content (all tests $\mathrm{p}<0.0001$ ) in $T$. cacao and $P$. guajava. Psidium guajava was the only species to present a significant increase of total carotenoids between intermediate radiation and direct sunlight, with values of 0.86 and $1.16 \mathrm{mg}$ $\mathrm{g}^{-1}$, respectively (an increase close to 35\%). In the other species, the changes in carotenoids were very low (close to $4 \%, 3 \%$ and $-1 \%$, for E. stipitata, T. cacao, and I. edulis, respectively).
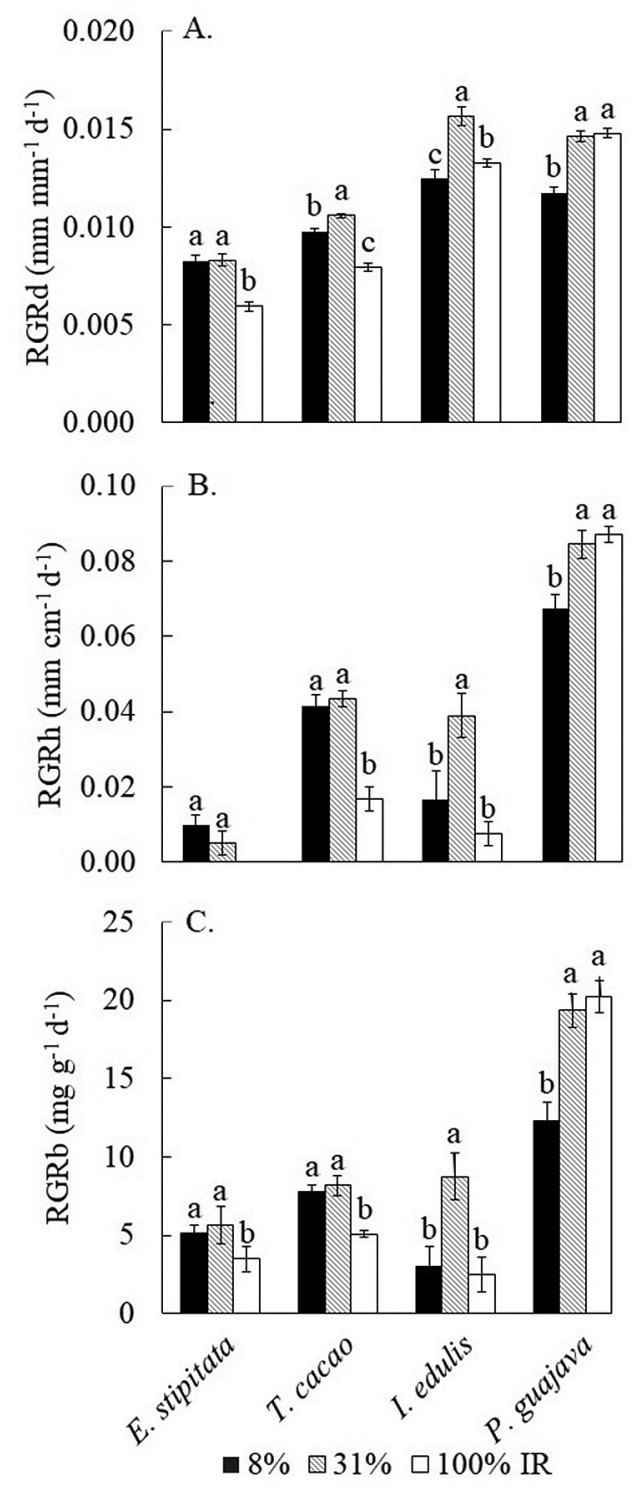

Figure 2. Diameter of root collar (RGRd) (A); height (RGRh) (B); and relative growth rate of biomass (RGRb) (C) in seedlings of Eugenia stipitata, Theobroma cacao, Inga edulis and Psidium guajava under three light treatments (8\%, 31\% and $100 \%$ RI) in shade houses. Columns are the mean and bars the standard deviation. Different letters above the bars indicate significant differences between treatments within species (all tests significant, RGRd, all tests $p<0.034$; RGRh, all tests $p<$ 0.009; RGRb, all tests $p<0.026 ; n=15$ ). 
Table 1. Total chlorophyll, total carotenoids, foliar area, conductance and total biomass in Eugenia stipitata, Theobroma cacao, Inga edulis, and Psidium guajava leaves growing under three light treatment $(8 \%, 31 \%$, and $100 \%$ RI) in shade houses. RI = relative illumination. Values are the mean \pm standard deviation. Different letters in the columns indicate significant difference between light treatments within species (all tests significant, except carotenoids in Eugenia stipitata and Inga edulis, both $p>0.528 ; n=15)$.

\begin{tabular}{lcccccc}
\hline Species & RI (\%) & $\begin{array}{c}\text { Chlorophyll } \mathrm{a}+\mathrm{b} \\
\left(\mathrm{mg} \mathrm{g}^{-1}\right)\end{array}$ & $\begin{array}{c}\text { Carotenoids } \\
\left(\mathrm{mg} \mathrm{g}^{-1}\right)\end{array}$ & $\begin{array}{c}\text { Foliar area } \\
\left(\mathrm{cm}^{2}\right)\end{array}$ & $\begin{array}{c}\text { Total biomass } \\
(\mathrm{g})\end{array}$ & $\begin{array}{c}\text { Stomatal conductance } \\
\left(\mathrm{mol} \mathrm{H}_{2} \mathrm{O} \mathrm{m}^{-2} \mathrm{~s}^{-1}\right)\end{array}$ \\
\hline E. stipitata & 8 & $5.46 \pm 0.13 \mathrm{a}$ & $0.23 \pm 0.021 \mathrm{a}$ & $512 \pm 39 \mathrm{a}$ & $82.28 \pm 14 \mathrm{a}$ & $0.084 \pm 0.025 \mathrm{a}$ \\
& 31 & $2.37 \pm 0.083 \mathrm{~b}$ & $0.27 \pm 0.017 \mathrm{a}$ & $583 \pm 59 \mathrm{a}$ & $85.56 \pm 10 \mathrm{a}$ & $0.093 \pm 0.028 \mathrm{a}$ \\
\hline T. cacao & 100 & $0.73 \pm 0.012 \mathrm{c}$ & $0.28 \pm 0.010 \mathrm{a}$ & $346 \pm 15 \mathrm{~b}$ & $53.5 \pm 11 \mathrm{~b}$ & $0.057 \pm 0.017 \mathrm{~b}$ \\
\hline I. edulis & 8 & $7.54 \pm 0.063 \mathrm{a}$ & $0.61 \pm 0.019 \mathrm{~b}$ & $5893 \pm 280 \mathrm{a}$ & $145.66 \pm 13 \mathrm{a}$ & $0.041 \pm 0.013 \mathrm{a}$ \\
& 31 & $4.96 \pm 0.033 \mathrm{~b}$ & $0.72 \pm 0.023 \mathrm{a}$ & $3585 \pm 194 \mathrm{~b}$ & $155.49 \pm 21 \mathrm{a}$ & $0.038 \pm 0.016 \mathrm{a}$ \\
& 100 & $1.94 \pm 0.013 \mathrm{c}$ & $0.74 \pm 0.018 \mathrm{a}$ & $1056 \pm 121 \mathrm{c}$ & $97.09 \pm 12 \mathrm{~b}$ & $0.022 \pm 0.007 \mathrm{~b}$ \\
\hline P. guajava & 8 & $5.73 \pm 0.032 \mathrm{a}$ & $0.75 \pm 0.033 \mathrm{a}$ & $4757 \pm 366 \mathrm{c}$ & $144.12 \pm 36 \mathrm{~b}$ & $0.108 \pm 0.033 \mathrm{c}$ \\
& 31 & $3.96 \pm 0.027 \mathrm{ab}$ & $0.76 \pm 0.023 \mathrm{a}$ & $7911 \pm 232 \mathrm{a}$ & $386.08 \pm 36 \mathrm{a}$ & $0.246 \pm 0.040 \mathrm{a}$ \\
& 100 & $2.40 \pm 0.018 \mathrm{~b}$ & $0.75 \pm 0.013 \mathrm{a}$ & $5683 \pm 722 \mathrm{~b}$ & $123.94 \pm 17 \mathrm{~b}$ & $0.185 \pm 0.034 \mathrm{~b}$ \\
\hline
\end{tabular}

\section{Chlorophyll fluorescence}

The effect of light treatment was significant for all species (all tests $\mathrm{p}<0.014)$. The mean daily values of maximum photochemical efficiency of the photosystem II (Fv/Fm) decreased significantly as the radiation level increased in $E$. stipitata, T. cacao and I. edulis, which suggests that these three species experienced chronic photoinhibitory processes (Figure 3). Leaves of E. stipitata and T. cacao experienced strong and pronounced chronic photoinhibition under the 100\% sunlight treatment, with values of $\mathrm{Fv} / \mathrm{Fm}$ under 0.7 (Figure 3). The effect was slighter in I. edulis exposed to $100 \%$ sunlight, with values of $\mathrm{Fv} / \mathrm{Fm}$ over 0.7 (Figure 3). In contrast, there was no evidence of chronic photoinhibition in $P$. guajava as differences in $\mathrm{Fv} / \mathrm{Fm}$ were non-significant $(\mathrm{p}=0.241)$ among light treatments.

The dynamics of Fv/Fm was evaluated throughout the day only in the environment with the most radiation (100\% RI) because it was the treatment that provoked negative changes in the plants for variables such as chlorophyll content, foliar area, total biomass (Table 1), photosynthesis rate (Figure 5), survival (Figure 6), and growth rates (Figure 2). The light treatment $\mathrm{x}$ time of day interaction was significant (both tests $\mathrm{p}<0.037$ ) for T. cacao and P. guajava and non-significant for E. stipitate and I. edulis (both tests $\mathrm{p}>0.491$ ). Psidium guajava and T. cacao showed a similar pattern of $\mathrm{Fv} / \mathrm{Fm}$ along the day. $\mathrm{Fv} / \mathrm{Fm}$ decreased significantly at midday with a recovery in the afternoon with respect to values recorded in the morning (Figure 4). Psidium guajava experienced the largest change in $\mathrm{Fv} / \mathrm{Fm}$ throughout the day: values close to 0.78 were recorded in the morning and afternoon, while there was a strong decrease at midday, reaching a mean value of 0.71 (Figure 4).

\section{Gas exchange measurements}

In the four species, maximum photosynthesis $\left(\mathrm{A}_{\max }\right)$ and stomatal conductance varied significantly among light

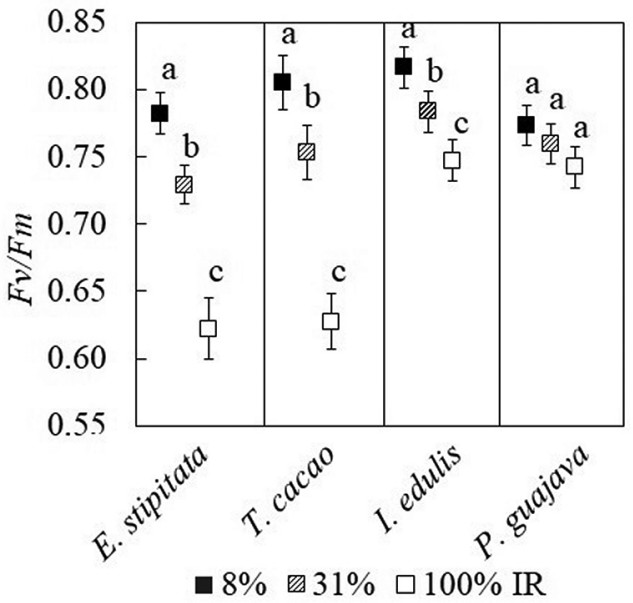

Figure 3. Maximum photochemical efficiency of PSII in dark-adapted leaves (Fv/ Fm) in seedlings of Eugenia stipitata, Theobroma cacao, Inga edulis and Psidium guajava under three light treatments (8\%, 31\% and 100\% RI). Boxes indicate the mean and bars the standard deviation. Different lowercase letters above the bars indicate significant differences between light conditions within species. Two-way ANOVA: light treatment, all tests significant, $p<0.014$ (except Psidium guajava, $p$ $=0.241$ ); time of the day, all tests non-significant, $p>0.185) ; n=15$.

treatments (all tests $<0.0190$ and $\mathrm{p}<0.0001$, respectively). $\mathrm{A}_{\max }$ increased from the most shaded to the intermediatelight treatment, which had the highest values (Figure 5). From intermediate light to full sunlight, E. stipitata, T. cacao and I. edulis presented a significant decrease in $\mathrm{A}_{\max }$ and stomatal conductance, while differences in P. guajava were non-significant.

\section{Survival}

Plant survival at the end of the experiment was not significantly influenced by the radiation treatment in $P$. guajava ( $\mathrm{p}=0.469)$, but varied significantly in the other species (all tests $\mathrm{p}<0.012$ ), with significantly lower values in 


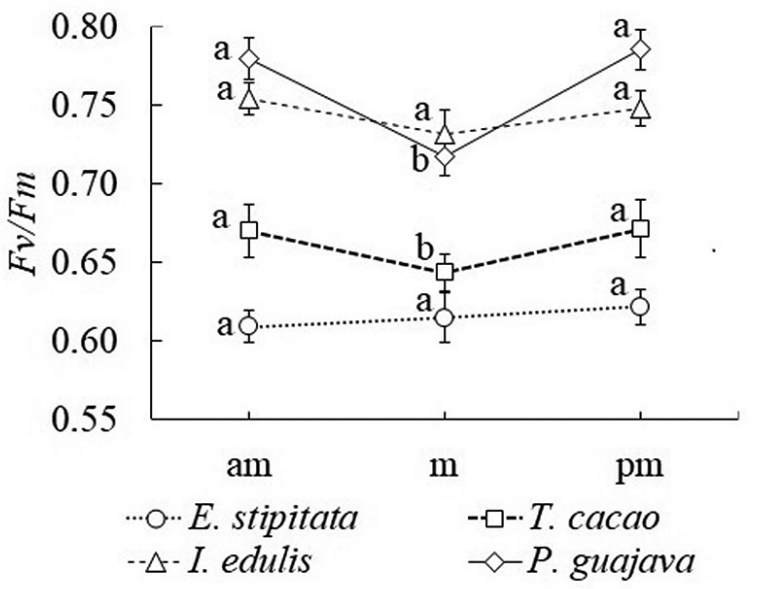

Figure 4. Changes in the maximum photochemical efficiency of PSII in darkadapted leaves (Fv/Fm) in Eugenia stipitata, Theobrom. cacao, Inga edulis, and Psidium guajava leaves grown under full sun light (100\% RI). Symbols indicate the mean and bars the standard deviation. Data were analyzed with a two-way ANOVA with light intensity and time of the day as independent factors. The interaction between the factors was significant for Theobroma cacao and Psidium guajava (both $p<0.037$ ) and non-significant for Eugenia stipitate and Inga edulis (both $p$ $>0.491) ; n=15$. Different letters above the bars indicate significant differences between hours within species.

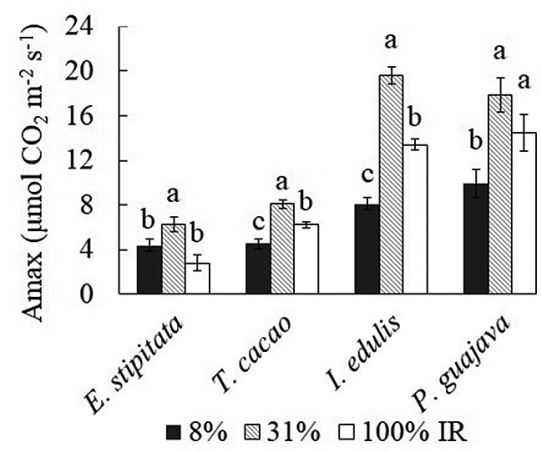

Figure 5. Maximum photosynthesis rate of mature leaves of Eugenia stipitata, Theobroma cacao, linga edulis and Psidium guajava seedlings grown under three light treatments (8\%, 31\% and 100\% Rl) in shade houses. Columns are the mean and bars the standard deviation. Different letters on the bars indicate significant differences between treatments within species (all tests significant at $p<0.019$; $n=3)$.

full sunlight in comparison with the other light treatments (Figure 6). Inga edulis and T. cacao had a similar survival rate in full sunlight, close to $70 \%$, while E. stipitata had only a $30 \%$ survival in this treatment.

\section{DISCUSSION}

Our results showed that the continuous exposure to intense and direct solar radiation induced physiological, pigment, photosynthetic, and growth changes in E. stipitata, T. cacao and I. edulis seedlings. Specifically, there were highly negative effects on the chlorophyll content, which decreased strongly. High radiation stimulates the production of reactive

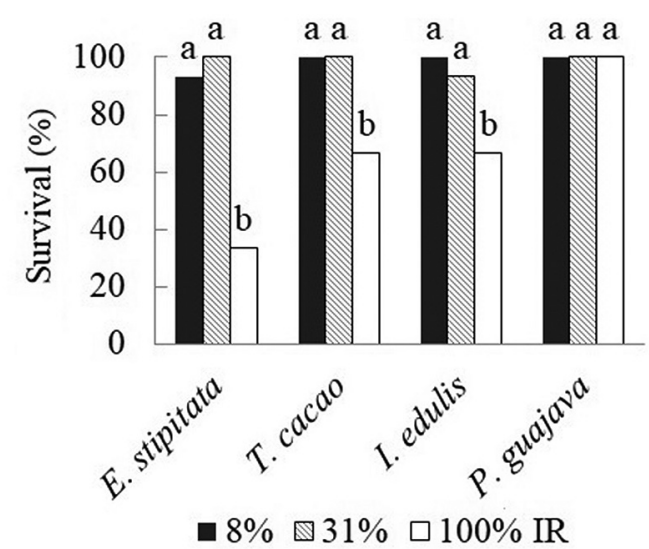

Figure 6. Mean survival (\%) of Eugenia stipitata, Theobroma cacao, Inga edulis and Psidium guajava under three different light treatments (8\%, 31\% and 100\% RI). Different letters indicate significant differences between treatments within species (all tests significant at $p<0.012$, except Psidium guajava, $p=0.469 ; n=15$ ).

oxygen species (ROS), which have a crucial role in pigment degradation in the chloroplasts (Takahashi et al. 2009; Choudhury et al. 2017). In this way, the deterioration of the photosynthetic pigments triggered photoinhibitory processes, as evidenced in the decrease in the quantum efficiency of the PSII $(\mathrm{Fv} / \mathrm{Fm})$ and the photosynthetic capacity $\left(\mathrm{A}_{\max }\right)$. This sensitivity of E. stipitata and T. cacao to high radiation is typical of shade-tolerant species. Both also required more shading than I. edulis. These results indicate that the above-mentioned syndromes (chlorophyll degradation, photoinhibitory processes, decrease in stomatal conductance and $\mathrm{CO}_{2}$ fixation) greatly influenced the increase in mortality and the drastic reduction of foliar area and growth rates in $E$. stipitata, T. cacao and I. edulis grown under full sunlight, as compared to the other treatments. These findings agree with Marimon et al. (2008), who found that biomass accumulation in Brosimum rubescens seedlings, a shade-tolerant tree species, was inhibited by direct sunlight. Accordingly, the highest values of stomatal conductance, foliar area, total biomass and growth rate of I. edulis occurred at moderate levels of radiation, while there were no significant differences between low and moderate radiation incidence for E. stipitata and $T$. cacao. A similar trend was observed for photosynthetic pigments and physiological variables, with a much higher chlorophyll content in the more shaded treatments for E. stipitata and T. cacao, which also presented higher levels of photoinhibition in full sunlight, as well as lower photosynthetic capacity in comparison with $I$. edulis and $P$. guajava.

The analysis of alterations in foliar area and pigments provides important information on the acclimation capacity of plants to full sun conditions and on the harmful effects of excessive radiation (Favaretto et al. 2011). In this context, and considering our results, the radiation intensity in the $100 \% \mathrm{RI}$ treatment did not cause modification to the photosynthetic apparatus of $P$. guajava, as we observed no significant reduction 
in total chlorophyll content. Therefore, this species did not exhibit chronic photoinhibitory processes, although it showed marked reduction of $\mathrm{Fv} / \mathrm{Fm}$ at midday, as there was a recovery in the afternoon. This physiological response occurs as a consequence of the inactivation-reactivation of the reaction centers, specifically in the D1 protein of the PSII (Nilkens et al. 2010), which acted as a dissipation mechanism for the excess of radiation in the form of heat, preventing severe damage to the photosynthetic apparatus at midday, when radiation is maximum (Oguchi et al. 2011; Takahashi and Badger 2011). These results support Adams et al. (2013) and DemmigAdams et al. (2012), who found that photoinhibition, more than having a deteriorating effect on plants, can be seen as a photo-regulation and acclimation strategy against high irradiation levels.

The elevated and significant increase of total carotenoids in response to the full sun treatment in P. guajava contributed to the dissipation of the excess radiation. This biochemical reaction has been recognized as an efficient light regulator inside leaves that acts as photoprotection mechanism (Cazzonelli et al. 2011). Our results are consistent with those reported by Sarijeva et al. (2007), who found that leaves of Ginkgo biloba L. and Fagus sylvatica L. (two pioneer species) exposed to full sunlight presented almost twice as much carotenoids as leaves that grew under partial shade, so avoiding the damaging effects of exposure to high intensity radiation. Likewise, the high performance of the pioneer species Cecropia pachystachya, Croton urucurana, Croton floribundus and Schinus terebinthifolius developing under full sunlight was accompanied by a significant increase in carotenoids and high Fv/Fm values (Favaretto et al. 2011).

Probably as a result of these physiological and biochemical responses, $P$. guajava did not present a significant reduction in its photosynthetic capacity $\left(\mathrm{A}_{\max }\right)$, stomatal conductance, foliar area and growth between $31 \%$ and $100 \%$ RI. However, there was also no significant increase in these variables under full sunlight, which probably occurred due to the energetic cost of the mechanisms the plants used to protect themselves against intense radiation (Oguchi et al. 2011). On one hand, there was an energy expenditure in the synthesis and maintenance of pigments (carotenoids and chlorophyll) and, on the other hand, the repair of the protein D1 associated with the temporary inactivation of the PSII complex should represent an additional cost to the plant (Raven 1989; Vass et al. 2012). These costs would explain that the P. guajava plants in $100 \%$ RI did not show higher growth, as seedlings in this treatment did not benefit from the higher availability of energy to gain carbon (Raven 1989; Goh et al. 2012). However, the pattern we observed for $P$. guajava apparently are not universal because responses to PAR changes in several tropical fruits considered to be light-demanding species are variable. For example, Mangifera indica L. cv. Ubá demonstrated ability to deal with changes of PAR, suggesting considerable phenotypic plasticity, although photoinhibitory damage was detected during the fruiting phase (Faria-Silva et al. 2017). In Carica papaya L., prolonged low light intensity can cause significant alterations of leaf anatomy and morphology, as well as increased chlorophyll content per unit leaf area and air space in the leaf mesophyll (Silva et al. 2019).

In summary, the combination of the biochemical and physiological mechanisms that characterized the response of $P$. guajava to the prolonged exposure to intense radiation enabled the plants to protect themselves against light stress (Mittal et al. 2011), which probably also contributed to the $100 \%$ survival observed in this species. As it is capable of maintaining a good photosynthetic performance, high growth rate and low mortality under intense sunlight, $P$. guajava can be considered a sun-loving species since its early growth stages.

\section{CONCLUSIONS}

Eugenia stipitata and T. cacao exhibited the lowest acclimatization capacity to full sunlight condition, followed by I. edulis. Practical implications of these responses are that these species must be grown under intermediate shade and protected from direct sunlight in their early growth stage, and that they have high potential of being successfully established under shade in AFS. In contrast, P. guajava seedlings demonstrated high tolerance to elevated radiation as a consequence of several biochemical and physiological mechanisms that effectively protect its leaves against the deleterious effects of high light intensity. Therefore, this species has the potential to use illuminated environments more efficiently. Consequently, $P$. guajava is more suitable to be established under direct sunlight and to provide shade for shade-tolerant species in AFSs.

\section{ACKNOWLEDGMENTS}

The authors thank the Departamento Administrativo de Ciencia, Tecnología e Innovación (COLCIENCIAS) and Universidad Nacional de Colombia for financing this research under Project "Respuestas fisiológicas de especies potenciales de árboles tutores de la vainilla (Vanilla planifolia) bajo condiciones microambientales contrastantes" (code \# 1118-521-28492). Corporación Colombiana de Investigación Agropecuaria - AGROSAVIA partially financed the writing of this document.

\section{REFERENCES}

Abbott, P.C.; Benjamin, T.J.; Burniske, G.R.; Croft, M.M.; Fenton, M.; Kelly, C.R.; Lundy, M.; Rodriguez Camayo, F.; Wilcox, M.D. 2018. An analysis of the supply chain of cacao in Colombia. USAID, Cali, 208p.

Adams, W.W.; Muller, O.; Cohu, C.M.; Demmig-Adams, B. 2013. May photoinhibition be a consequence, rather than a cause, of limited plant productivity? Photosynthesis Research, 117: 31-44. 
Avila-Lovera, E.; Coronel, I.; Jaimez, R.; Urich, R.; Pereyra, G.; Araque, O.; Tezara, W. 2016. Ecophysiological traits of adult trees of Criollo cocoa cultivars (Theobroma cacao L.) from a germplasm bank in Venezuela. Experimental Agriculture, 52: 137-153.

Bazzaz, F.A.; Pickett, S.T.A. 1980. Physiological ecology of tropical succession: a comparative review. Annual Review of Ecology and Systematics, 11: 287-310.

Barth, C., \& Krause, G. H. 1999. Inhibition of photosystems I and II in chilling-sensitive and chilling-tolerant plants under light and low-temperature stress. Zeitschrift für Naturforschung $C$, 54(9-10), 645-657.

Braga, D.P.; Domene, F.; Gandara, F.B. 2019. Shade trees composition and diversity in cacao agroforestry systems of southern Pará, Brazilian Amazon. Agroforestry Systems, 93: 1409-1421.

Cazzonelli, C.I. 2011. Carotenoids in nature: insights from plants and beyond. A review. Functional Plant Biology, 38: 833-847.

Charbonnier, F.; Roupsard, O.; Le Maire, G.; Guillemot, J.; Casanoves, F.; Lacointe, A. 2017. Increased light-use efficiency sustains net primary productivity of shaded coffee plants in agroforestry system. Plant, Cell and Environment, 40: 1592-1608.

Choudhury, F.K.; Rivero, R.M.; Blumwald, E.; Mittler, R. 2017. Reactive oxygen species, abiotic stress and stress combination. The Plant Journal, 90: 856-867.

Demmig-Adams, B.; Cohu, C.M.; Muller, O.; Adams, W.W. 2012. Modulation of photosynthetic energy conversion efficiency in nature: from seconds to seasons. Photosynthesis Research, 113: 75-88.

Dos Santos, U.M.; de Carvalho, J.F.; Fearnside, P.M. 2013. Measuring the impact of flooding on Amazonian trees: photosynthetic response models for ten species flooded by hydroelectric dams. Trees, 27: 193-210.

Favaretto, V.F.; Martinez, C.A.; Soriani, H.H; Furriel R.P. 2011. Differential responses of antioxidant enzymes in pioneer and late-successional tropical tree species grown under sun and shade conditions. Environmental Experimental Botany, 70: 20-28.

Faria-Silva, L.; Gallon, C.Z.; Purgatto, E.; Silva, D.M. 2017. Photochemical metabolism and fruit quality of Ubá mango tree exposed to combined light and heat stress in the field. Acta Physiologiae Plantarum, 39. https://doi.org/10.1007/s11738017-2533-3

Fischer, G.; Miranda, D.; Melgarejo, L.M. 2012. Manual para el cultivo de frutales en el trópico. Guayaba. Produmedios, Bogotá, $44 \mathrm{p}$.

García, J.A.; Hernández, M.S.; Muñoz, L.M. 2011. Arazá; Estudios ecofisiológicos en la Amazonia Colombiana. Editores Gigiprint, Bogotá, 104p.

Goh, C.H.; Ko, S.M.; Koh, S.; Kim, Y.J.; Bae, H.J. 2012. Photosynthesis and environments: photoinhibition and repair mechanisms in plants. Plant Biology, 55: 93-101.

Iqbal, R.M.; Rao, A.R.; Rasul, E.; Wahid, A. 1997. Mathematical models and response functions in photosynthesis: an exponential model. In: Pessarakli, M. (Ed.). Handbook of photosynthesis. Marcel Dekker Inc., New York, p.803-810.
Krause, G.; Winter, K.; Matsubara, S.; Krause, B.; Jahns P.; Virgo, A.; Aranda J.; García, M. 2012. Photosynthesis; photoprotection; and growth of shade-tolerant tropical tree seedlings under full sunlight. Photosynthesis Research, 113: 273-285.

Lichtenthaler, H.K. 1987. Chlorophylls and carotenoids: pigments of photosynthetic biomembranes. Methods in Enzymology, 148: 350-382.

Lichtenthaler, H.K.; Wellburn, A.R. 1983. Determinations of total carotenoids and chlorophyll $a$ and $b$ of leaf extracts in different solvents. Biochemical Society, 603: 591-592.

Lojka, B.; Dumas, L.; Preininger, D.; Polesny, Z.; Banout, J. 2010. The use and integration of Inga edulis in agroforestry systems in the Amazon - review article. Agricultura Tropica et Subtropica, 43: 352-359.

Marimon, B.S.; Felfili, J.M.; Marimon, B.H.; Franco, A.C.; Fagg, C.W. 2008. Desenvolvimento inicial e partição de biomassa de Brosimum rubescens Taub (Moraceae) sob diferentes níveis de sombreamento. Acta Botanica Brasilica, 22: 941-953.

Mittal, S.; Kumari, N.; Shamara, V. 2011. Differential responses of seven contrasting species to high light using pigment and chlolophyll a fluorescence. Journal of Stress Physiology and Biochemistry, 7: 20-33.

Nichols, J.D.; Carpenter, F.L. 2006. Interplanting Inga edulis yields nitrogen benefits to Terminalia amazonia. Forest Ecology and Management, 233: 344-351.

Nilkens, M.; Kress, E.; Lambrev, P.; Miloslavina, Y.; Müller, M.; Holzwarth, A.R.; Jahns, P. 2010. Identification of a slowly inducible zeaxanthin-dependent component of nonphotochemical quenching of chlorophyll fluorescence generated under steady-state conditions in Arabidopsis. BBA Bioenergetics 1797: 466-475.

Nygren, P.; Leblanc, H.A.; Lu, M.; Luciano, C.A. 2013. Distribution of coarse and fine roots of Theobroma cacao L. and shade tree Inga edulis in a cocoa plantation. Annals of Forest Science, 70: 229-239.

Oguchi, R.; Terashima, I.; Kou, J.; Chow, W.S. 2011. Operation of dual mechanisms that both lead to photoinactivation of photosystem II in leaves by visible light. Physiologia Plantarum, 142: 47-55.

Rai, M.K.; Asthana, P.; Jaiswal, V.S.; Jaiswal, U. 2010. Biotechnological advances in guava (Psidium guajava L.): recent developments and prospects for further research. Trees, 24: 1-12.

Raven, J.A. 1989. Fight or flight: The economics of repair and avoidance of photoinhibition of photosynthesis. Functional Ecology, 3: 5-19.

Sarijeva, G.; Knapp, M.; Lichtenthaler, H.K. 2007. Differences in photosynthetic activity; chlorophyll and carotenoid levels and in chlorophyll fluorescence parameters in green sun and shade leaves of Ginkgo and Fagus. Plant Physiology, 164: 950-955.

Silva, J.R.; Rodrigues, W.P.; Ruas, K.F.; Paixão, J.S.; Nunes de Lima, R.S.; Garcia, J.A.C.; Campostrini, E. 2019. Light, photosynthetic capacity and growth of papaya (Carica papaya L.): A short review. Australian Journal of Crop Science, 13: 480-485.

Takahashi, S., Milward, S. E., Fan, D. Y., Chow, W. S., \& Badger, M. R. 2009. How does cyclic electron flow alleviate photoinhibition in Arabidopsis?. Plant Physiology, 149(3), 1560-1567. 
Takahashi, S.; Badger, M.R. 2011. Photoprotection in plants: a new light on photosystem II damage. Trends in Plant Science, 16: 53-60.

Tremblay, S.; Lucotte, M.; Revéret, J.P.; Davidson, R.; Mertens, F.; Passos, C.J.S.; Romana, C.A. 2015. Agroforestry systems as a profitable alternative to slash and burn practices in small-scale agriculture of the Brazilian Amazon. Agroforestry Systems, 89: 193-204.

Vass, I. 2012. Molecular mechanisms of photodamage in the Photosystem II complex. Biochimica et Biophysica Acta, 1817: 209-217.

Yang, Y.J.; Liu, T.; Zhang, S.B.; Huang, W. 2020. Photoinhibition of oxygen-evolving complex and photosystem II at chilling stress in the tropical tree species Dalbergia odorifera. Photosynthetica, 58: 245-252.

Zuidema, P.A.; Leffelaar, P.A.; Gerritsma, W.; Mommer, L.; Anten, N.P. 2005. A physiological production model for cocoa (Theobroma cacao): model presentation; validation and application. Agricultural Systems, 84: 195-225

RECEIVED: 02/03/2020

ACCEPTED: 08/11/2020

ASSOCIATE EDITOR: Tomas F. Domingues 